University of the Pacific

Scholarly Commons

5-1-2016

\title{
Advances in endodontics: Potential applications in clinical practice.
}

Anil Kishen

Ove A. Peters

University of the Pacific, opeters@pacific.edu

Matthias Zehnder

Anibal R. Diogenes

Madhu K. Nair

Follow this and additional works at: https://scholarlycommons.pacific.edu/dugoni-facarticles

Part of the Dentistry Commons

\section{Recommended Citation}

Kishen, A., Peters, O. A., Zehnder, M., Diogenes, A. R., \& Nair, M. K. (2016). Advances in endodontics: Potential applications in clinical practice.. Journal of Conservative Dentistry, 19(3), 199-206. DOI: 10.4103/0972-0707.181925

https://scholarlycommons.pacific.edu/dugoni-facarticles/361

This Article is brought to you for free and open access by the All Faculty Scholarship at Scholarly Commons. It has been accepted for inclusion in All Dugoni School of Dentistry Faculty Articles by an authorized administrator of Scholarly Commons. For more information, please contact mgibney@pacific.edu. 


\title{
Advances in endodontics: Potential applications in clinical practice
}

\author{
Anil Kishen, Ove A. Peters ${ }^{1}$, Matthias Zehnder ${ }^{2}$, Anibal R. Diogenes ${ }^{3}$, Madhu K. Nair ${ }^{4}$
}

Department of Endodontics, University of Toronto, Toronto, Ontario, Canada, 'Department of Endodontics, Arthur A Dugoni School of Dentistry, University of the Pacific, San Francisco, California, ${ }^{3}$ Department of Endodontics, University of Texas Health Science Center, San Antonio, Texas, ${ }^{4}$ Department of Radiology, College of Medicine, University of Florida, Gainesville, Florida, USA, ${ }^{2}$ Department of Preventive Dentistry, Periodontology and Cariology, Division of Endodontology, University of Zürich Center for Dental Medicine, Zürich, Switzerland

\begin{abstract}
A b st r a c t
Contemporary endodontics has seen an unprecedented advance in technology and materials. This article aimed to review some of the challenges and advances in the following sections: (1) endodontic imaging, (2) root canal preparation, (3) root canal disinfection, (4) root canal filling, and (4) regenerative endodontic procedures (REPs). Jointly, these advances are aimed at improving the state of the art and science of root canal treatment.
\end{abstract}

Keywords: Canal preparation; disinfection; endodontic imaging; filling; regeneration

\section{INTRODUCTION}

The past couple of decades have witnessed one of the most rapid and extensive technological evolutions in dentistry. This period has presented some remarkable developments of endodontic technologies. The current article is aimed to concisely review some of these advances pertinent to endodontic imaging, root canal preparation, root canal disinfection, root filling, and regenerative endodontic procedures (REPs).

\section{ENDODONTIC IMAGING}

Analog and digital imaging modalities are available for use in diagnostic endodontic imaging. The National Council for Radiation Protection (NCRP) report \#145 recommends the use of the fastest speed sensor with rectangular collimation to conform to the as low as reasonably achievable (ALARA) principle while capturing analog images. Analog imaging presents several disadvantages: Need for repeat exposure

\section{Address for correspondence:}

Dr. Anil Kishen, Faculty of Dentistry,

University of Toronto, 124 Edward Street,

Toronto, ON M5G 1G6, Canada.

E-mail: anil.kishen@utoronto.ca

Date of submission : 22.01.2016

Review completed : 07.02.2016

Date of acceptance : 05.04.2016

\begin{tabular}{|l|l|}
\hline \multicolumn{2}{|c|}{ Access this article online } \\
\hline Quick Response Code: & Website: \\
\hline & www.jcd.org.in \\
\cline { 2 - 2 } & \\
\hline
\end{tabular}

in suboptimal image capture situations, inability to enhance images interactively, wet processing issues, and difficulty in acquiring/transmitting images electronically, all of which have resulted in the adoption of digital technology. Digital capture systems include electronic sensors [digital radiography (DR)] such as a charge-coupled device (CCD) or a complementary metal oxide semiconductor (CMOS) while indirect systems use photostimulable phosphor (PSP) plates. This is known as computed radiography (CR). The advantages of digital imaging include significant dose reduction, relatively faster image acquisition, ability to enhance images, elimination of wet processing, easier transmission, and archival of images.

Currently hardwired and wireless sensors are available for use. DR offers the highest spatial and contrast resolution but the latitude is limited. CR offers wider latitude. Both have been shown to be as good as intraoral film or better for endodontic diagnoses. Most have active areas that are slightly smaller than film but more than sufficient for endodontic purposes. Advantages of CMOS over CCD include a lower manufacturing cost, need for a lesser amount of electrical energy for functioning, and comparable spatial/contrast resolution for diagnostic

This is an open access article distributed under the terms of the Creative Commons Attribution-NonCommercial-ShareAlike 3.0 License, which allows others to remix, tweak, and build upon the work non-commercially, as long as the author is credited and the new creations are licensed under the identical terms.

For reprints contact: reprints@medknow.com

How to cite this article: Kishen A, Peters OA, Zehnder M, Diogenes AR, Nair MK. Advances in endodontics: Potential applications in clinical practice. J Conserv Dent 2016;19:199-206. 
purposes. Presently available wireless sensors, including the newly introduced CMOS-APS sensors (Wifi Schick Elite sensor, Sirona Dental Inc., Long Island City, NY, USA) are less bulky and transmit signals via a thinner wire that enables wireless transmission and lasts for about 100 exposures.

PSP plates are wireless and activated by adding an impurity to the phosphor, thus rendering it sensitive to incident radiation. Charges are generated and stored in the form of a latent image following exposure. Exposing to white light would erase the plates and allow reusability. PSP plates require almost the same amount of exposure as an F-speed film with rectangular collimation. Plates are significantly less expensive than CCD or CMOS sensors. However, in endodontics instantaneous chairside acquisition of images with relatively high contrast and spatial resolution is required, which is best served by CMOS sensors. ${ }^{[1]}$ Since multiple images are frequently needed, use of a sensor that requires the least amount of radiation to produce a high quality image is optimal in endodontics.

The processing of film carries several new recommendations as well. Transitioning to DR will help clinicians get into compliance fairly easily. For periapical and bitewing radiography, rectangular collimation should be used whenever possible because a round field beam used with a rectangular image receptor produces unnecessary radiation exposure to the patient. The human visual system is seriously limited in terms of the shades of gray it can view at any one point in time. Therefore, adjusting the display properties of the image optimizes visualization of the signal of interest. Images must be saved in a universal Digital Imaging and Communication in Medicine (DICOM) format for best fidelity and ease of transmission between imaging systems of different vendors. The compression scheme used does not result in loss of image data. Most newer systems permit a 16-bit depth ( $2^{16}$ shades of gray) capture for an image. The file size is large and therefore, stored in a compressed format without the loss of diagnostic information (8-bit data).

The advent of cone beam computed tomography (CBCT) has resulted in widespread adoption of this technology for three-dimensional image capture/processing. Computed tomography greatly enhances diagnostic yield in certain situations where two-dimensional conventional radiographic studies have limitations. However, care should be exercised not to prescribe CBCTs for all endodontic procedures due to the fact that the radiation dose to the patient is significantly higher than those from conventional studies. ${ }^{[2]}$ Apart from this, the presence of artifacts, noise, and lower spatial resolution as compared to conventional radiographs preclude the generation of useful images in several clinical scenarios. It is imperative that recommendations from the updated position paper on the use of CBCT in endodontics be carefully followed to keep doses to the minimum while maximizing diagnostic information from such cases. Several CBCT units are available with varying fields of view (FOV). Shortest scan times should be used with the smallest field of view and the smallest available voxel size without compromising on the signal to noise ratio but without a massive reduction in radiation as this would seriously degrade the signal quality. Voxel sizes range 76-500 microns but endodontic applications require voxel sizes of less than 200 microns for optimal spatial resolution. Those that employ smaller fields of view have smaller voxel dimensions. The existing literature supports the use of CBCT in clinical endodontics for selected diagnostic tasks, on a case-by-case basis, following a thorough clinical evaluation.

Few clinical studies have validated the use of CBCT in endodontics with the help of ground truth. Most are in vitro/ ex vivo studies, the results of which cannot be extrapolated to the clinical scenario. Care must be exercised in the use of CBCT in pediatric patients, in view of the fact that the American Academy of Oral and Maxillofacial Radiology (AAOMR) and American Association of Endodontists (AAE) support the Image Gently Campaign led by the Alliance for Radiation Safety in Pediatric Imaging to help minimize the radiation dose to children. Some of the potential applications of CBCT include diagnoses related to the following: Initial diagnosis where nonspecific signs and symptoms exist, dental anomalies and developmental disturbances, presence of anatomic variations, calcified canals, broken instruments, vertical root fractures, failure of prior treatment, nonsurgical and surgical retreatments, select cases of trauma, resorption (external and internal), and implant placement..$^{[3,4]}$

\section{ROOT CANAL PREPARATION}

All treatment steps in endodontics need to be assessed under the premise of antimicrobial effectiveness ${ }^{[5]}$ and canal preparation is no exception. Root canal preparation serves to remove intracanal tissue (in vital cases) and necrotic material including microbial biofilms (in necrotic cases). In addition, an adequately shaped canal accepts irrigation solutions as well as interappointment medication and is ultimately filled optimally.

Engine-driven instrumentation continues to be used more frequently by endodontists compared to hand instruments. ${ }^{[6]}$ At this point, several trends are observed in the marketplace:

a. Application of more flexible alloys, which not only promises better canal negotiation but also extend the fatigue life.

b. Practice of reciprocation motion and potentially reduction of the number of instruments used per patient.

c. Introduction of instruments that are designed to 
instrument a larger area of the canal wall and decrease the need for coronal flaring.

The following section will explore these trends and summarize expectations for the future. Table 1 provides an overview of current nickel-titanium rotary instruments.

Due to its specific metallurgical properties, nickel-titanium (NiTi) alloy can be manufactured so that it is, for example, at body temperature, predominantly either in austenitic or martensitic crystal configuration. ${ }^{[7]}$ These two crystal configurations have distinctly different properties, with austenite being less flexible but allowing up to $7 \%$ recoverable elastic deformation range. ${ }^{[8]}$ Conversely, martensite can be dead-soft and very flexible but only allows about $2 \%$ linear strain before nonrecoverable plastic deformation occurs. ${ }^{[9]}$ With these differences in flexibility, distinct differences in fatigue resistance are observed: martensitic files have significantly extended lifespans..$^{[9]}$ Some martensitic instruments are designed to have deformations removed during sterilization cycles while reprocessing; however, regularly certain residual deformation still remains. ${ }^{|10|}$ The development of specific heat treatment and production methods continues, which includes the fine tuning of the crystal conversion temperature so that instruments may for instance be very flexible when on the shelf while assuming a different shape and behaving more rigidly when placed in a root canal.

Currently, most practitioners use electric motors to power rotary instruments. These motors are also undergoing development. The ability to set a torque limit is common to most electric motors but many models currently allow reciprocating action. While this is not entirely new, ${ }^{[11]}$ several NiTi instruments have been developed entirely for reciprocation motion with unequal angles of rotation. Reciprocation movement has been shown to be efficient and safe ${ }^{[12]}$ In particular, fatigue lifespan of a file is extended with reciprocation design. ${ }^{[13]}$ Irrigation efficiency in infected root canal systems may be facilitated by instrumentation via mechanical force ${ }^{[14]}$ and perhaps a scraping action of instruments along the canal walls. ${ }^{[15]}$ Toward this several techniques were initiated in the last few years, beginning with the so-called self-adjusting file. ${ }^{[16]}$

Clinical observations suggest that not only healing of apical periodontitis but also extended mechanical function of teeth is an important endodontic outcome. ${ }^{[17,18]}$ Since it is well-understood that the major factor that increases fracture susceptibility in endodontically treated teeth is the removal of bulk dentin during access ${ }^{[19,20]}$ and canal preparation, ${ }^{[21,22]}$ strategies are being developed that retain more dentin, ${ }^{[23]}$ specifically in the coronal root third ${ }^{[24,25]}$ during shaping. One strategy to achieve this goal is to limit coronal flaring and perhaps the so-called maximum fluted diameter (MFD). A more radical change would occur if a completely noninstrumental technique without the use of any canal preparation was to be adopted. Such a technique was experimented years ago $^{[26]}$ requiring an airtight connection to the access cavity; currently, a noninstrumental canal disinfection system, based on ultrasonic activation, is being researched in vitro. ${ }^{[27]}$

In summary, most current instruments perform well when used judiciously; apical canal transportation, a measure

Table 1: Nickel-titanium root canal preparation instruments introduced after 2010

\begin{tabular}{|c|c|c|c|}
\hline Name & Manufacturer & Description (tip diameter) & Production process \\
\hline BioRace, BT Race, iRace & FKG-Brasseler & $\begin{array}{l}\text { Triangular cross-section, multiple sequences, cont. rot. } \\
(10 / .06-50 / .06)\end{array}$ & Grinding, electropolishing \\
\hline EdgeFile $\times 1,3,5,7$ & Edge Endo & Parabolic cross-section, cont. rot., (17/.04-40/.06) & Grinding, heat treatment \\
\hline Hyflex/Hyflex CM & Coltene & $\begin{array}{l}\text { Triangular cross-section, cont. rot., martensitic alloy } \\
(15 / .04-40 / .06)\end{array}$ & Grinding (electrical discharge machining) \\
\hline $\mathrm{K} 3 \mathrm{XF}$ & Kerr Sybron & $\begin{array}{l}\text { Complex cross-section, R-phase alloy, cont. rot. } \\
(15 / .04-60 / .06)\end{array}$ & Grinding, heat treatment \\
\hline OneShape & MicroMega & Two s-shapes cross-sections, cont. rot. (25/.06) & Grinding, heat treatment \\
\hline ProTaper gold & $\begin{array}{l}\text { Dentsply Tulsa } \\
\text { Dental }\end{array}$ & $\begin{array}{l}\text { Variable tapers, partly martensitic alloy, cont. rot. (17-50, } \\
\text { various apical tapers) }\end{array}$ & Grinding, heat treatment \\
\hline ProTaper next & $\begin{array}{l}\text { Dentsply Tulsa } \\
\text { Dental }\end{array}$ & $\begin{array}{l}\text { Variable tapers, rectangular off-centered cross-section, } \\
\text { cont. rot. (17/.04-50/.06) }\end{array}$ & $\begin{array}{l}\text { Grinding, heat treatment, } \\
\text { electropolishing }\end{array}$ \\
\hline Reciproc & VDW & $\begin{array}{l}\text { Two flutes in s-shaped cross-section, Reciprocation with } \\
\text { unequal angles }(25,40,50)\end{array}$ & Grinding, heat treatment \\
\hline SAF & $\begin{array}{l}\text { Redent Nova } \\
\text { Henry Schein }\end{array}$ & 2 sizes, hollow-tube mesh, in-out-translational movement & Laser cutting, heat treatment \\
\hline TF Adaptive & Kerr Sybron & Multiple sizes, special motor with various rotation modes & Twisting, heat treatment \\
\hline TRUShape & $\begin{array}{l}\text { Dentsply Tulsa } \\
\text { Dental }\end{array}$ & $\begin{array}{l}\text { Triangular cross-section S-shaped, cont. rot. (20-40, } \\
\text { conforming taper) }\end{array}$ & Grinding, heat treatment, form-pressing \\
\hline Typhoon & DS Dental & $\begin{array}{l}\text { Triangular cross-section, martensitic alloy, cont. rot. } \\
(20 / .04-35 / .06)\end{array}$ & Grinding \\
\hline WaveOne & Dentsply Maillefer & $\begin{array}{l}\text { Reciprocation with unequal angles, currently } 3 \text { tip sizes } \\
(21,25,40 \text {, various apical tapers) }\end{array}$ & Grinding, electropolishing \\
\hline Vortex Blue & $\begin{array}{l}\text { Dentsply Tulsa } \\
\text { Dental }\end{array}$ & $\begin{array}{l}\text { Triangular cross-section, partly martensitic alloy cont. rot. } \\
(15 / .04-50 / .06)\end{array}$ & Grinding, heat treatment \\
\hline
\end{tabular}


of shaping quality, is typically under $150 \mu \mathrm{m} .{ }^{[28]}$ Flexibility and resistance to fatigue of the instruments are increasing. Current and future developments of instruments and strategies are aimed to provide antibiofilm effects and remove less radicular dentin structure. As shaping alone is not sufficient to reduce microbial loads, adequate irrigation strategies will continue to complement canal preparation. ${ }^{[29]}$

\section{ROOT CANAL DISINFECTION}

Complexities of the root canal systems, in addition to the structure and composition of the dentin, are key challenges for effective disinfection in endodontics. Topical antimicrobial such as sodium hypochlorite is commonly used in root canal treatment to combat microbial biofilms. The inability of antimicrobials to eliminate biofilm bacteria in the anatomical complexities and uninstrumented portions of the root canal would compromise their efficacy in root canal treatment. Irrigation dynamics deals with how irrigants flow, penetrate, and exchange within the root canal space and the forces produced by them. Unfortunately, the widely used syringe-based irrigation displayed a passive flow of irrigant at the apical region, 1-3 $\mathrm{mm}$ beyond the exit of the needle. The syringebased method also failed to generate optimum levels of shear stresses on the canal wall, which is significant for disinfecting root canal biofilms. Thus, steps taken to improve the delivery of irrigant (irrigation dynamics) within the root canal system are crucial to achieve the maximum efficacy out of the antimicrobials. The current advances in endodontic disinfection are aimed toward:

a. Improving the fluid dynamics during root canal irrigation - improving bubble dynamics and activating intensified cavitational bubbles are some of the mechanisms by which fluid dynamics can be improved.

b. Developing newer antimicrobials, which demonstrate potent antibiofilm effect over sodium hypochlorite. ${ }^{[30]}$

\section{Antibacterial nanoparticles}

Nanoparticles (NPs) are microscopic particles with one or more dimensions in the range of $1-100 \mathrm{~nm}$. It is established that NPs have properties that are very unique from their bulk counterparts. Antibacterial NP has been found to have a broad spectrum of antimicrobial activity and far lower propensity to induce microbial resistance. The electrostatic interaction between positively charged NPs and negatively charged bacterial cells, and the accumulation of large number of NPs on the bacterial cell membrane have been associated with the leading to the loss of membrane permeability and rapid loss of membrane function. ${ }^{[30]}$ The ability of some of the tested NPs to rapidly eliminate biofilm bacteria needs further improvement. However, when sealers are loaded with NP, they displayed a superior ability to diffuse the antibacterial component deep into the dentin. ${ }^{[31]}$ Studies have stressed their role as an intracanal medicament than an irrigant, and to improve the antimicrobial effectiveness of root canal sealers. ${ }^{[32]}$ Currently, functionalized NPs are being developed to eliminate bacteria more specifically without damaging the host cells (targeted antibacterial efficacy) and to repair previously infected dentin matrix. ${ }^{\text {[33,34] }}$

\section{Antimicrobial photodynamic therapy}

Antimicrobial photodynamic therapy (APDT) is a two-step procedure that involves the application of a photosensitizer (PS) (step-1), followed by light illumination (step 2) of the sensitized tissue, which would generate a toxic photochemistry on the target cell, leading to microbial killing. Currently, APDT is considered not an alternative but a possible supplement to the existing protocols for root canal disinfection. ${ }^{[30]}$ In an approach to adapt and improve the antimicrobial efficacy of APDT in endodontics, recent research has developed novel formulations of photosensitizers that displayed effective penetration into dentinal tubules, anatomical complexities, and antibiofilm properties. Well-designed clinical studies are currently warranted to examine the prospects for APDT in root canal disinfection. ${ }^{[35,36]}$

\section{Photon-induced photoacoustic streaming}

Photon-induced photoacoustic streaming (PIPS) is based on the direct shock wave generated by a erbium:YAG (Er:YAG) laser (Fidelis AT; Fotona, Ljubljana, Slovenia) in a liquid irrigant. The laser system is equipped with a fiberoptic delivery tip and subablative parameters to produce the desired effect. When activated in a limited volume of fluid, the high absorption of Er:YAG wavelength combined with the high peak power derived from the short pulse duration resulted in an enhanced bubble dynamics, which improved the irrigant flow dynamics within the root canal. The current literature presents conflicting findings on this technology. ${ }^{[37-39]}$ This demands further evaluation and modifications of this technology to optimize therapeutic efficacy through the root canal system..$^{40]}$

\section{Gentlewave irrigation}

Gentlewave (GW) (Sonendo, Laguna Hills, CA, USA) has been developed and tested for root canal irrigation. It delivers sodium hypochlorite into the root canal under pressure through a specialized handpiece, which is activated by a broad spectrum of acoustic waves. At the same time, suction removes the outflowing fluid through the handpiece. A silicon ring surrounding the extremity of the handpiece creates a tight seal with the artificially created flat tooth surface. This establishes a vented and closed-loop fluid flow within the root canal. ${ }^{[27]}$ This system is expected to enhance irrigation dynamics in minimally enlarged root canals. Studies are currently being performed to assess the ability of the GW system to disinfect the root canal biofilms. ${ }^{[37]}$ 
In summary, many advanced antimicrobial strategies are being tested and developed to enhance antibiofilm efficacy within the root canal system. These techniques are focused toward potent antibiofilm methods and optimized irrigant delivery systems to achieve essential goals in root canal treatment. Further clinical research is required in this area.

\section{ADVANCES IN ROOT FILLING}

To complete a root canal treatment in a mature tooth, the root canal system is filled with synthetic materials. A predictable alternative to this technique is currently elusive. It may be possible in the future to attract pulp-like tissue into the cleaned and shaped root canals. ${ }^{[41]}$ However, the translation of tissue engineering concepts to everyday clinics has not yet been made and thus, the current focus to improve the conventional approach to fill the root canals will still remain.

Primarily, the root-filling is expected to provide a hermetic seal against microorganisms, be tissue-friendly, easy to apply, monitor, and retrieve in case of treatment failure. These requirements are not always met by current filling materials. ${ }^{[42]}$ The core of the problem with current materials is that a so-called hermetic seal is not easy to achieve.

Why is a hermetic seal difficult to achieve in root canals? Any material that is used to fill the small anatomical intricacies of a tooth needs to be applied in a plastic state. Later, this material should be dimensionally stable. With the synthetic materials used in dentistry, this means that some form of physical or chemical reaction takes place between the application of a filling material and its final state. In the context of filling root canals, we encounter the problem that the configuration factor ( $\mathrm{C}$-factor), which is the ratio between bonded to nonbonded area of a filling material, is extremely high in the root canals..$^{[43,44]}$ This means that the volume shrinkage is more detrimental to the cohesiveness of the tooth and filling in this environment than in the crown of the tooth. When a material alters its state, it usually changes its dimensions. For root-filling materials in particular, dimensional changes should be kept minimal. While most current sealers, especially those based on an epoxy resin or silicone, are dimensionally stable ${ }^{[45]}$ the core material is not. In current root-filling techniques, guttapercha (essentially polyisoprene with a high zinc oxide filler content) is used as a core material. It is heated to become plastic, and applied in conjunction with a sealer. However, it was well-recognized that thermoplasticized gutta-percha shrinks upon cooling. ${ }^{[46]}$

Some newer concepts: Two related concepts have evolved over the recent years that might improve and simplify root-filling procedures. The first approach is to use a calcium silicate cement-based sealer. ${ }^{[47,48]}$ These sealers are initially flowable and express bioactive properties, i.e., they promote $\mathrm{Ca} / \mathrm{P}$ precipitation in a wet environment. As the root canal system is inherently wet ${ }^{[49]}$ the use of bioactive filling materials is logical. ${ }^{[48]}$ The interface that forms between sealer and root canal wall is calcium phosphate and thus, mimics nature. Since calcium-silicate cements set hard, a core material is still necessary, which remains to be gutta-percha. Consequently, root-fillings with calcium-silicate cements still have two interfaces:

a. Between the sealer and the canal wall, and

b. Between the sealer and the gutta-percha. ${ }^{[50]}$

Hence, calcium silicate sealers per se do not conclusively solve the root-filling conundrum.

In a recent approach, bioactive particles were embedded in the matrix (polycaprolactone) of the core filling material. ${ }^{[51]}$ This matrix material was thermoplasticized and used as the sole material to fill root canals, thus reducing the interface between filling and tooth to one, with rather promising results in vitro. However, polycaprolactone appears not to be an ideal material for root-fillings, as it is biodegradable..$^{[52]} \mathrm{A}$ later approach used nanometric bioactive glass particles of the 45S5 type embedded in the gutta-percha matrix. ${ }^{[53]}$ In contrast to conventional gutta-percha, this material showed immediate sealing properties when applied in heated form. A premarket radiopaque material was later introduced and tested for its self-adhesiveness to the root dentin ${ }^{[54]}$ and tissue compatibility. ${ }^{[55]}$ The initial in vitro results were promising, yet the material has to be scrutinized clinically before final recommendation.

Complex application schemes ${ }^{[56]}$ and uncontrolled/extended thermal shrinkage $e^{[57,58]}$ are some of the challenges in current root-filling. Newer nanomaterial-based approaches are showing promise for the future.

\section{REGENERATIVE ENDODONTICS}

The treatment of immature teeth with pulpal necrosis represents a major clinical challenge. The untoward advent of pulpal necrosis arrests the developmental process in immature teeth. ${ }^{[59]}$ The challenges related to treating these cases far exceed the technical challenges of debriding and obturating a large root canal space with thin dentinal walls, and lacking an apical constriction. These teeth have been traditionally treated with apexification procedures. Although these procedures are quite successful in arresting the infectious process and resolving apical periodontitis, they fail to promote continued root development and normal physiological pulpal responses. Thus, immature teeth remain with thin fragile dentinal walls becoming susceptible to fractures and lower survival. Further, implants are contraindicated in patients undergoing cranioskeletal development. Thus, there has been an unmet need to 
provide adequate treatment to patients with immature teeth with pulpal necrosis.

The field of regenerative endodontics emerged in early 2000s with the publication of two remarkable case reports. ${ }^{[60,61]}$ Since then, there have been more than 200 published cases demonstrating that these procedures allow unprecedented results. ${ }^{[59,62,63]}$ These include:

1. Resolution of apical periodontitis and signs and symptoms of pulpal inflammation;

2. Radiographic evidence of continued root development and apical narrowing; and

3. Restoration of vitality responses.

Importantly, these published cases demonstrate that REPs address the unmet need of promoting normal physiological development and responses in immature teeth diagnosed with pulpal necrosis.

In most REPs, clinicians rely on creating bleeding from the apical region that passively fills the canal space and forms a blood clot. However, it was not until 2011 that a clinical study demonstrated that the influx of apical blood into disinfected root canals allowed a significant transfer of stem cells into the root canal system. This was a very important pivoting moment in this young field of regenerative endodontics since it established that these procedures were in fact, stem cell-based procedures. The realization that stem cells were present in root canals during these procedures propelled researchers to investigate the effect of various steps usually employed on these procedures on stem cell fate.

The balance between adequate disinfection and stem cell survival, proliferation, and differentiation represents an important first barrier to be overcome. The resolution of infection and the disease process remains the primary goal of any endodontic procedure. However, it has become obvious that the philosophy of disinfecting the root canal at all costs typically advocated in traditional root canal therapy had to be modified to a "biocompatible disinfection" strategy. For example, sodium hypochlorite remains the most used disinfectant in endodontics. ${ }^{[64]}$ However, its use at full concentration of $6 \%$ denatures crucial growth factors in the dentin ${ }^{[65]}$ and results in residual detrimental effects greatly affecting stem cell survival and differentiation potential. ${ }^{[66-68]}$ These effects can be largely avoided with the use of the concentration of $1.5 \%$ followed by $17 \%$ EDTA. ${ }^{[68,69]}$ Another example is the long-lasting detrimental effects of using high concentrations of antibiotic pastes (approximately $1 \mathrm{~g} / \mathrm{mL}$ ) as intracanal medicament on stem cells. At this concentration, triple antibiotic paste (minocycline, metronidazole, and ciprofloxacin) have longlasting effects on stem cell survival through both direct and indirect mechanisms. ${ }^{[70,71]}$ This undesirable carryover effect can be greatly avoided by the use calcium hydroxide as intracanal medicament ${ }^{[0,71]}$ or the use of these pastes in lower concentrations $(<1 \mathrm{mg} / \mathrm{mL})$ while maintaining their desirable antibacterial effect. ${ }^{\text {72,73] }}$ Therefore, there has been significant advancement in understanding how to adapt currently used disinfection protocols to the reality of stem cell-based therapies.

Apart from biocompatible disinfection, many other frontiers in regenerative endodontic research are being currently investigated. These involves tissue engineering strategies that include the evaluation of suitable scaffolds, growth factors, and harvested stem cells to be used in pulpal regeneration. ${ }^{[74]}$ Importantly, many of the advances from translational research have been transferred to clinical practice such as the use of platelet-rich plasma, ${ }^{175,76]}$ platelet fibrin, ${ }^{177]}$ and a gelatin hydrogel ${ }^{[78]}$ as scaffolds in patients. In addition, a groundbreaking clinical trial is currently in process in Japan. This trial involves harvesting stem cells from a donor site followed by ex vivo expansion, sorting, and autotransplantation into a recipient tooth to promote the regeneration of the once lost functional pulp-dentin complex. ${ }^{[79]}$ These elegant studies highlight the current status and sophistication of REPs.

In summary, significant advances in regenerative endodontics allow better understanding of a multitude of factors that govern stem cell-mediated regeneration and repair of the damaged pulp-dentin complex. Translational research is proving to be crucial in making these procedures more predictable while pushing the boundaries of future procedures that are likely to involve the direct clinical manipulation of scaffolds, growth factors, and stem cells.

\section{Financial support and sponsorship}

Nil.

\section{Conflicts of interest}

There are no conflicts of interest.

\section{REFERENCES}

1. Nair MK, Nair UP. Digital and advanced imaging in endodontics: A review. J Endod 2007;33:1-6.

2. ADA Council on Scientific Affairs. An update on radiographic practices: Information and recommendations. ADA Council on Scientific Affairs. J Am Dent Assoc 2001;132:234-8.

3. American Association of Endodontists; American Academy of Oral and Maxillofacial Radiolog. Use of cone-beam computed tomography in endodontics Joint Position Statement of the American Association of Endodontists and the American Academy of Oral and Maxillofacial Radiology. Oral Surg Oral Med Oral Pathol Oral Radiol Endod 2011;111:234-7.

4. Tyndall DA, Price JB, Tetradis S, Ganz SD, Hildebolt C, Scarfe WC; American Academy of Oral and Maxillofacial Radiology. Position statement of the American Academy of Oral and Maxillofacial Radiology on selection criteria for the use of radiology in dental implantology with emphasis on cone beam computed tomography. Oral Surg Oral Med Oral Pathol Oral Radiol 2012;113:817-26.

5. Ørstavik D, Pitt Ford T. Essentials in Endodontology. $2^{\text {nd }}$ ed. Oxford: Blackwell Munksgaard; 2008. p. 1-488.

6. Bird DC, Chambers D, Peters OA. Usage parameters of nickel-titanium rotary instruments: A survey of endodontists in the United States. J Endod 2009;35:1193-7. 
7. Thompson SA. An overview of nickel-titanium alloys used in dentistry. Int Endod J 2000;33:297-310.

8. Otsuka K, Ren X. Physical metallurgy of Ti-Ni-based shape memory alloys. Progr Mat Sci 2005;50:511-678.

9. Shen Y, Zhou HM, Zheng YF, Peng B, Haapasalo M. Current challenges and concepts of the thermomechanical treatment of nickel-titanium instruments. J Endod 2013;39:163-72.

10. Peters OA, Gluskin AK, Weiss RA, Han JT. An in vitro assessment of the physical properties of novel Hyflex nickel-titanium rotary instruments. Int Endod J 2012;45:1027-34.

11. Hülsmann M, Peters OA, Dummer PM. Mechanical preparation of root canals: Shapinhg goals, techniques and means. Endod Topics 2005;10:30-76

12. Yared G. Canal preparation using only one Ni-Ti rotary instrument: Preliminary observations. Int Endod J 2008;41:339-44.

13. Perez-Higueras JJ, Arias A, de la Macorra JC. Cyclic fatigue resistance of $\mathrm{K} 3, \mathrm{~K} 3 \mathrm{XF}$, and twisted file nickel-titanium files under continuous rotation or reciprocating motion. J Endod 2013;39:1585-8.

14. Koch J, Borg J, Mattson A, Olsen K, Bahcall J. An in vitro comparative study of intracanal fluid motion and wall shear stress induced by ultrasonic and polymer rotary finishing files in a simulated root canal model. ISRN Dent 2012;2012:764041.

15. Peters OA, Schönenberger K, Laib A. Effects of four Ni-Ti preparation techniques on root canal geometry assessed by micro computed tomography. Int Endod J 2001;34:221-30.

16. Metzger Z, Teperovich E, Zary R, Cohen R, Hof R. The self-adjusting file (SAF). Part 1: Respecting the root canal anatomy--a new concept of endodontic files and its implementation. J Endod 2010;36:679-90.

17. Ng YL, Mann V, Gulabivala K. A prospective study of the factors affecting outcomes of nonsurgical root canal treatment: Part 1: Periapical health. Int Endod J 2011;44:583-609.

18. Ng YL, Mann V, Gulabivala K. A prospective study of the factors affecting outcomes of non-surgical root canal treatment: Part 2: Tooth survival. Int Endod J 2011;44:610-25.

19. Reeh ES, Messer HH, Douglas WH. Reduction in tooth stiffness as a result of endodontic and restorative procedures. J Endod 1989;15:512-6.

20. Krishan R, Paqué F, Ossareh A, Kishen A, Dao T, Friedman S. Impacts of conservative endodontic cavity on root canal instrumentation efficacy and resistance to fracture assessed in incisors, premolars, and molars. J Endod 2014;40:1160-6.

21. Lang H, Korkmaz $\mathrm{Y}$, Schneider $\mathrm{K}$, Raab WH. Impact of endodontic treatments on the rigidity of the root. J Dent Res 2006;85:364-8.

22. Zelic K, Vukicevic A, Jovicic G, Aleksandrovic S, Filipovic N, Djuric M. Mechanical weakening of devitalized teeth: Three-dimensional finite element analysis and prediction of tooth fracture. Int Endod $\mathrm{J}$ 2015;48:850-63.

23. Gluskin $\mathrm{AH}$, Peters $\mathrm{Cl}$, Peters OA. Minimally invasive endodontics: Challenging prevailing paradigms. Br Dent J 2014;216:347-53.

24. Degerness RA, Bowles WR. Dimension, anatomy and morphology of the mesiobuccal root canal system in maxillary molars. $J$ Endod 2010;36:985-9.

25. Garala M, Kuttler S, Hardigan P, Steiner-Carmi R, Dorn S. A comparison of the minimum canal wall thickness remaining following preparation using two nickel-titanium rotary systems. Int Endod J 2003;36:636-42.

26. Lussi A, Nussbächer U, Grosrey J. A novel noninstrumented technique for cleansing the root canal system. J Endod 1993;19:549-53.

27. Haapasalo M, Wang Z, Shen Y, Curtis A, Patel P, Khakpour M. Tissue dissolution by a novel multisonic ultracleaning system and sodium hypochlorite. J Endod 2014;40:1178-81.

28. Peters OA, Paque F. Current developments in rotary root canal instrument technology and clinical use: A review. Quintessence Int 2010;41:479-88.

29. Peters OA, Paque F. Shaping the root canal system to promote disinfection. In: Cohenca N, editor. Disinfection of root canal systems. $1^{\text {st }}$ ed. Ames IA, Oxford UK: Wiley Blackwell; 2014. p. 91-108.

30. Kishen A. Advanced therapeutic options for endodontic biofilms. Endod Topics 2010;22:99-123.

31. Kishen A, Shi Z, Shrestha A, Neoh KG. An investigation on the antibacterial and antibiofilm efficacy of cationic nanoparticulates for root canal disinfection. J Endod 2008;34:1515-20.

32. Wu D, Fan W, Kishen A, Gutmann JL, Fan B. Evaluation of the antibacterial efficacy of silver nanoparticles against Enterococcus faecalis biofilm. J Endod 2014;40:285-90.

33. ShresthaA, Kishen A. Antibiofilm efficacy of photosensitizer-functionalized bioactive nanoparticles on multispecies biofilm. $J$ Endod 2014;40:1604-10.

34. Shrestha A, Hamblin MR, Kishen A. Photoactivated rose bengal functionalized chitosan nanoparticles produce antibacterial/biofilm activity and stabilize dentin-collagen. Nanomedicine 2014;10:491-501.
35. George S, Kishen A. Photophysical, photochemical, and photobiological characterization of methylene blue formulations for light-activated root canal disinfection. J Biomed Opt 2007;12:034029.

36. George S, Kishen A. Augmenting the antibiofilm efficacy of advanced noninvasive light activated disinfection with emulsified oxidizer and oxygen carrier. J Endod 2008;34:1119-23.

37. Peters OA, Bardsley S, Fong J, Pandher G, Divito E. Disinfection of root canals with photon-initiated photoacoustic streaming. J Endod 2011;37:1008-12.

38. Pedullà E, Genovese C, Campagna E, Tempera G, Rapisarda E. Decontamination efficacy of photon-initiated photoacoustic streaming (PIPS) of irrigants using low-energy laser settings: An ex vivo study. Int Endod J 2012;45:865-70.

39. Zhu X, Yin X, Chang JW, Wang Y, Cheung GS, Zhang C. Comparison of the antibacterial effect and smear layer removal using photon-initiated photoacoustic streaming aided irrigation versus a conventional irrigation in single-rooted canals: An in vitro study. Photomed Laser Surg 2013:31:371-7.

40. George R, Chan K, Walsh LJ. Laser-induced agitation and cavitation from proprietary honeycomb tips for endodontic applications. Lasers Med Sci 2015;30:1203-8.

41. Mao JJ, Kim SG, Zhou J, Ye L, Cho S, Suzuki T, et al. Regenerative endodontics: Barriers and strategies for clinical translation. Dent Clin North Am 2012;56:639-49.

42. Gatewood RS. Endodontic materials. Dent Clin North Am 2007;51:695-712, vii.

43. Bouillaguet S, Troesch S, Wataha JC, Krejci I, Meyer JM, Pashley DH. Microtensile bond strength between adhesive cements and root canal dentin. Dent Mater 2003;19:199-205.

44. Tay FR, Loushine RJ, Lambrechts P, Weller RN, Pashley DH. Geometric factors affecting dentin bonding in root canals: A theoretical modeling approach. J Endod 2005;31:584-9.

45. Ørstavik D, Nordahl I, Tibballs JE. Dimensional change following setting of root canal sealer materials. Dent Mater 2001;17:512-9.

46. Schilder H, Goodman A, Aldrich W. The thermomechanical properties of gutta-percha. Part V. Volume changes in bulk gutta-percha as a function of temperature and its relationship to molecular phase transformation. Oral Surg Oral Med Oral Pathol 1985;59:285-96.

47. Huffman BP, Mai S, Pinna L, Weller RN, Primus CM, Gutmann JL, et al. Dislocation resistance of ProRoot Endo Sealer, a calcium silicate-based root canal sealer, from radicular dentine. Int Endod J 2009;42:34-46.

48. Prati C, Gandolfi MG. Calcium silicate bioactive cements: Biological perspectives and clinical applications. Dent Mater 2015;31:351-70.

49. Papa J, Cain C, Messer HH. Moisture content of vital vs endodontically treated teeth. Endod Dent Traumatol 1994;10:91-3.

50. Tay FR, Pashley DH. Monoblocks in root canals - A hypothetical or a tangible goal. J Endod 2007;33:391-8.

51. Alani A, Knowles JC, Chrzanowski W, Ng YL, Gulabivala K. Ion release characteristics, precipitate formation and sealing ability of a phosphate glass-polycaprolactone-based composite for use as a root canal obturation material. Dent Mater 2009;25:400-10.

52. Tay FR, Pashley DH, Yiu CK, Yau JY, Yiu-fai M, Loushine RJ, et al. Susceptibility of a polycaprolactone-based root canal filling material to degradation. II. Gravimetric evaluation of enzymatic hydrolysis. J Endod 2005;31:737-41.

53. Mohn D, Bruhin C, Luechinger NA, Stark WJ, Imfeld T, Zehnder M. Composites made of flame-sprayed bioactive glass $45 \mathrm{~S} 5$ and polymers: Bioactivity and immediate sealing properties. Int Endod J 2010;43:1037-46.

54. Marending M, Bubenhofer SB, Sener B, De-Deus G. Primary assessment of a self-adhesive gutta-percha material. Int Endod J 2013;46:317-22.

55. Belladonna FG, Calasans-Maia MD, Novellino Alves AT, de Brito Resende RF, Souza EM, Silva EJ, et al. Biocompatibility of a self-adhesive gutta-percha-based material in subcutaneous tissue of mice. J Endod 2014;40:1869-73.

56. Schilder H. Filling root canals in three dimensions. Dent Clin North Am 1967:723-44.

57. Lottanti S, Tauböck TT, Zehnder M. Shrinkage of backfill gutta-percha upon cooling. J Endod 2014;40:721-4.

58. Lee CQ, Chang Y, Cobb CM, Robinson S, Hellmuth EM. Dimensional stability of thermosensitive gutta-percha. J Endod 1997;23:579-82.

59. Diogenes A, Henry MA, Teixeira FB, Hargreaves KM. An update on clinical regenerative endodontics. Endod Topics 2013;28:2-23.

60. Banchs F, Trope M. Revascularization of immature permanent teeth with apical periodontitis: New treatment protocol? J Endod 2004;30:196-200.

61. Iwaya SI, Ikawa M, Kubota M. Revascularization of an immature permanent tooth with apical periodontitis and sinus tract. Dent Traumatol 2001;17:185-7. 
Kishen, et al.: Advances in endodontics

62. Kontakiotis EG, Filippatos CG, Tzanetakis GN, Agrafioti A. Regenerative endodontic therapy: A data analysis of clinical protocols. J Endod 2015;41:146-54.

63. Hargreaves KM, Diogenes A, Teixeira FB. Treatment options: Biological basis of regenerative endodontic procedures. Pediatr Dent 2013;35:129-40.

64. Harrison JW, Hand RE. The effect of dilution and organic matter on the anti-bacterial property of $5.25 \%$ sodium hypochlorite. $J$ Endod 1981;7:128-32.

65. Zhao S, Sloan AJ, Murray PE, Lumley PJ, Smith AJ. Ultrastructura localisation of TGF-beta exposure in dentine by chemical treatment. Histochem J 2000;32:489-94.

66. Trevino EG, Patwardhan AN, Henry MA, Perry G, Dybdal-Hargreaves N, Hargreaves KM, et al. Effect of irrigants on the survival of human stem cells of the apical papilla in a platelet-rich plasma scaffold in human root tips. J Endod 2011;37:1109-15.

67. Casagrande L, Demarco FF, Zhang Z, Araujo FB, Shi S, Nör JE. Dentin-derived BMP-2 and odontoblast differentiation. J Dent Res 2010;89:603-8.

68. Galler KM, D'Souza RN, Federlin M, Cavender AC, Hartgerink JD, Hecker S, et al. Dentin conditioning codetermines cell fate in regenerative endodontics. J Endod 2011;37:1536-41.

69. Martin DE, De Almeida JF, Henry MA, Khaing ZZ, Schmidt CE, Teixeira FB, et al. Concentration-dependent effect of sodium hypochlorite on stem cells of apical papilla survival and differentiation. J Endod 2014;40:51-5.

70. Ruparel NB, Teixeira FB, Ferraz CC, Diogenes A. Direct effect of intracanal medicaments on survival of stem cells of the apical papilla. J Endod 2012;38:1372-5.
71. Althumairy RI, Teixeira FB, Diogenes A. Effect of dentin conditioning with intracanal medicaments on survival of stem cells of apical papilla. J Endod 2014;40:521-5.

72. Sabrah AH, Yassen GH, Liu WC, Goebel WS, Gregory RL, Platt JA. The effect of diluted triple and double antibiotic pastes on dental pulp stem cells and established Enterococcus faecalis biofilm. Clin Oral Investig 2015;19:2059-66.

73. Sabrah $\mathrm{AH}$, Yassen $\mathrm{GH}$, Gregory RL. Effectiveness of antibiotic medicaments against biofilm formation of enterococcus faecalis and porphyromonas gingivalis. J Endod 2013;39:1385-9.

74. Albuquerque MT, Valera MC, Nakashima M, Nör JE, Bottino MC Tissue-engineering-based strategies for regenerative endodontics. J Dent Res 2014:93:1222-31.

75. Sachdeva GS, Sachdeva LT, Goel M, Bala S. Regenerative endodontic treatment of an immature tooth with a necrotic pulp and apical periodontitis using platelet-rich plasma (PRP) and mineral trioxide aggregate (MTA): A case report. Int Endod J 2015;48:902-10.

76. Torabinejad $M$, Turman $M$. Revitalization of tooth with necrotic pulp and open apex by using platelet-rich plasma: A case report. J Endod 2011;37:265-8.

77. Shivashankar VY, Johns DA, Vidyanath S, Kumar MR. Platelet rich fibrin in the revitalization of tooth with necrotic pulp and open apex. J Conserv Dent 2012;15:395-8.

78. Nagy MM, Tawfik HE, Hashem AA, Abu-Seida AM. Regenerative potential of immature permanent teeth with necrotic pulps after different regenerative protocols. J Endod 2014;40:192-8.

79. Nakashima M, lohara K. Mobilized dental pulp stem cells for pulp regeneration: Initiation of clinical trial. J Endod 2014;40(Suppl):S26-32. 
Copyright of Journal of Conservative Dentistry is the property of Medknow Publications \& Media Pvt. Ltd. and its content may not be copied or emailed to multiple sites or posted to a listserv without the copyright holder's express written permission. However, users may print, download, or email articles for individual use. 